\title{
A New Methoxyiminoacetamide Fungicide, SSF-126, May Concomitantly Exert Fungicidal Activity with Constituents in Healthy Rice Leaves
}

\author{
Ryuichi KUME*, Motomu NIIKAWA**, Akira KAWAGUCHI**, Keiichirou YASUMI** \\ Michio MASUKO** and Tomonori SHIRAISHI***
}

Key words : Pyricularia oryzae (Magnaporthe grisea), rice blast, SSF-126, methoxyiminoacetamide, fungicide, rice leaf component.

Since the respiratory inhibitor group of strobilurins were introduced into the agrochemical field in $1992^{1,3)}$, structural modifications and studies on their mode of action have progressed aggressively. $\beta$-Methoxyacrylate and $\alpha$-methoxyiminoacetate, which also inhibit respiration, have been introduced as promising candidates in a new class of broad-spectrum fungicides ${ }^{1,2}$.

A new methoxyiminoacetamide fungicide, $(E)-2$ methoxyimino- $N$-methyl-2-(2-phenoxyphenyl)acetamide (SSF-126), exhibits almost the same biological performance as strobilurin analogues or methoxyacrylates. Although it shows weak fungicidal activity in vitro, control of a wide range of plant diseases was excellent ${ }^{4,6)}$. Notably, SSF-126 gives excellent control against rice blast by foliar and submerged applications ${ }^{9)}$, even though the concentration of SSF-126 in rice plants varied between 0.9 and $0.2 \mathrm{ppm}$ from 1 to 104 days after submerged application (180 g a.i./10 a) ${ }^{12)}$. The infection hyphae of Pyricularia oryzae Cav. [teleomorph, Magnaporthe grisea (Hebert) Barr.] were restricted to only a few cells even at 5 days after inoculation ${ }^{5}$.

In regard to a direct action of SSF-126 on the fungus, Mizutani et al ${ }^{8)}$ reported that the compound strongly inhibited mitochondrial respiration in $P$. oryzae, by blockading electron flux through the cytochrome $b_{1}$ segment. However, respiration was restored within 60 minutes after incubation with SSF-126, since an alternative pathway resistant to $\mathrm{KCN}$ was induced in the SSF-126-treated mycelia.

In spite of its fungistatic nature and poor inhibition of fungal penetration, SSF-126 exhibited excellent control of blast disease when it was applied to the rice plant as described above. These results suggest that some component(s) in the rice plant may play an important role in the in vivo control of rice blast by SSF-126. This paper deals with the effect of rice leaf homogenates on the fungicidal activity of SSF-126 in terms of spore germination of $P$. oryzae.

SSF-126 was synthesized at Aburahi Laboratories, Shionogi \& Co. Ltd. (Shiga, Japan). Tests on conidial germination of $P$. oryzae were carried out on potato dextrose (PD) medium containing various concentrations of SSF-126. $P$. oryzae race 003 was grown on an oatmeal agar medium containing $2 \%$ sucrose at $28^{\circ} \mathrm{C}$ for 6 days under a black-light blue lamp (FL20S BLB, wavelength $352-440 \mathrm{~nm}, 20 \mathrm{~W}$, Toshiba Co., Tokyo, Japan). Equal volumes of conidial suspension $\left(1 \times 10^{5}\right.$ conidia/ml in PD liquid medium) and SSF-126 at twofold of its final concentration in distilled water containing less than $1 \%$ acetone were mixed on a glass slide. After incubation at $25^{\circ} \mathrm{C}$ in a moist container for the appropriate period, germinated conidia were counted under a light microscope and the percent of germination was calculated. SSF-126 inhibited conidial germination dose-dependently. However, even in $100 \mu \mathrm{g} / \mathrm{ml}$ solution of SSF-126, germination recovered after treatment ; at a rate that was also dependent on the concentration of SSF-126 (Fig. 1). The results show that SSF-126 is not fungicidal.

Some compounds are well-known for not inhibiting conidial germination or hyphal growth of $P$. oryzae but still giving control of rice blast by inhibiting melanization of appressoria and consequently inhibiting penetration into the host cell ${ }^{12}$. For this reason, the effect of SSF-126 on appressorial formation and pigmentation, as well as penetration through a cellulose membrane, was assessed after exposure to estimated concentrations of the compound in rice plants. Equal volumes of a conidial suspension and SSF-126 at two fold of its final concentration were mixed as described above. The mixture $(20$ $\mu$ l) was dropped onto a cellulose membrane (Size 18 $\mathrm{mm} \times 18 \mathrm{~mm}$, Sankou Junyaku, Tokyo, Japan). After incubation at $25^{\circ} \mathrm{C}$ for $24 \mathrm{hr}$ in a moist container, conidial germination was counted as described above. Appres-

* Agrochemical and Animal Health Products Technical Service Department, Shionogi \& Co., Ltd., Akoh 678-02, Japan 塩野義製薬株式会社動植楽技術部

** Aburahi Laboratories, Shionogi \& Co., Ltd., Koka-cho, Koka-gun, Shiga 520-34, Japan＼cjkstart塩野義製薬株式会社油日ラボ ラトリーズ

*** Laboratory of Plant Pathology and Genetic Engineering, College of Agriculture, Okayama University, Okayama 700, Japan 岡山大学農学部 


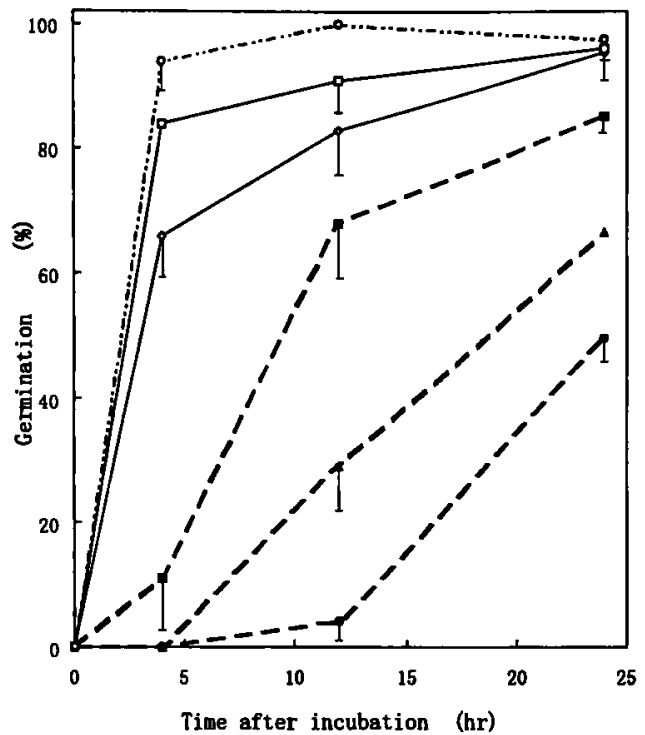

Fig. 1. Time course of the effect of SSF-126 on conidial germination of Pyricularia oryzae. Conidia were incubated with $100(\bullet), 10(\Delta), 1.0(\square), 0.1(\supset), 0.01(\square)$ and $0(O) \mu \mathrm{g} / \mathrm{ml}$ of SSF-126. Each value presented the mean with SD (the bar) from triplicate experiments.

sorial formation and penetration through the cellulose membrane were observed under the light microscope at 24 and $72 \mathrm{hr}$ after incubation, respectively.

Although SSF-126 inhibited appressorial formation to less than half of the control at $1.0 \mathrm{ppm}$, the conidial germination and hyphal penetration were not severely affected (Table 1). SSF-126 did not inhibit melanization of appressoria at all. The inhibitory effect of SSF-126 on appressorial formation seems to be a consequence of depression of energy production in the fungal mitochondria as described previously ${ }^{8}$. In other words, SSF-126 seems to express its controlling effects after penetration into the host plant.

The effect of SSF-126 on conidial germination of $P$. oryzae was further examined in the presence of rice homogenate. Rice (Oryza sativa L. cv. Aichiasahi) seeds were sown in plastic cups containing sterilized sand and grown for 40 days in a greenhouse. The leaves and

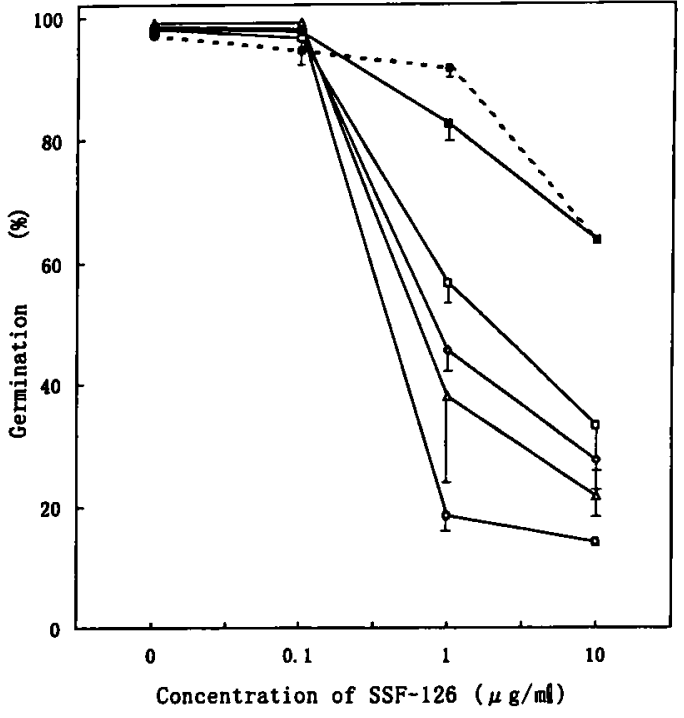

Fig. 2. Effects of rice leaf homogenates on the inhibi. tory effect of SSF-126 on conidial germination of Pyricularia oryzae. Tests were carried out at $25^{\circ} \mathrm{C}$ for $24 \mathrm{hr}$ in potato dextrose medium containing various concentration of SSF-126 with $125(\bigcirc), 62.5(\Delta), 31.25(\diamond), 15.63(\square), 7.82(\square)$ and $0(\bullet) \mathrm{mg}$ fresh weight equivalent $/ \mathrm{ml}$ of rice leaf homogenate. Each value presented the mean with SD (the bar) from triplicate experi. ments.

sheaths of the rice seedlings were harvested and homogenized with a three-fold $(\mathrm{w} / \mathrm{w})$ volume of $1 / 15 \mathrm{M}$ phosphate buffer $(\mathrm{pH} 6.9)$ in a chilled homogenizer. After the homogenate was centrifuged at $3000 \mathrm{rpm}$ for $5 \mathrm{~min}$, the supernatant was used for the conidial germination test. Slides were prepared and germination measured at $24 \mathrm{hr}$ as described above. As shown in Fig. 2, rice leaf homogenate alone did not inhibit germination at all. However, in the concomitant presence of the homogenate, SSF-126 strongly inhibited germination even at $1 \mu \mathrm{g} / \mathrm{ml}$. For example, $10 \mu \mathrm{g} / \mathrm{ml}$ of SSF-126 alone inhibited only about $30 \%$ of germination (Fig. 1), whereas it gave $80 \%$ inhibition in the concomitant presence with $125 \mathrm{mg}$ fresh weight equivalent $/ \mathrm{ml}$ of the homogenate. Furthermore, SSF-126 was not metabol-

Table 1. Effect of SSF-126 on appressorial formation and pigmentation and penetration into a cellulose membrane of Pyricularia oryzae

\begin{tabular}{|c|c|c|c|c|c|}
\hline Compound & $\begin{array}{l}\text { Conc. } \\
\text { (ppm) }\end{array}$ & $\begin{array}{l}\% \text { of Conidial } \\
\text { germination }\end{array}$ & $\begin{array}{c}\% \text { of Appressorium } \\
\text { formation }^{\text {b) }}\end{array}$ & $\begin{array}{c}\% \text { of } \\
\text { Penetration }\end{array}$ & $\begin{array}{c}\text { Color of } \\
\text { appressorium }\end{array}$ \\
\hline \multirow[t]{2}{*}{ SSF-126 } & 1.0 & $85.2 \pm 5.4$ & $21.0 \pm 2.8$ & $49.5 \pm 3.4$ & Greyish-black \\
\hline & 0.1 & $95.5 \pm 0.7$ & $49.5 \pm 0.5$ & $52.5 \pm 5.7$ & Greyish-black \\
\hline \multirow[t]{2}{*}{ Pyroquilon } & 1.0 & $96.5 \pm 0.7$ & $47.0 \pm 5.6$ & $1.0 \pm 0.1$ & Reddish-tan \\
\hline & 0.1 & $98.0 \pm 0.7$ & $49.3 \pm 2.4$ & $34.0 \pm 5.7$ & Tan \\
\hline Control & 0 & $97.5 \pm 0.5$ & $50.0 \pm 1.4$ & $57.0 \pm 0.5$ & Greyish-black \\
\hline
\end{tabular}

a) Assessed $24 \mathrm{hr}$ after incubation.

b) (No. of appressoria/No. of germinated conidia) $\times 100$, assessed $24 \mathrm{hr}$ after incubation.

c) (No. of penetrating hyphae/No. of appressoria) $\times 100$, assessed $72 \mathrm{hr}$ after incubation.

d) Assessed $72 \mathrm{hr}$ after incubation by microscopic observation. 
ized or converted to fungitoxic compounds in the rice plant or by the rice homogenate (details will be shown elsewhere).

Some component(s) in the rice leaf tissues were thought to enhance the fungicidal activity of SSF-126 at concentrations below that in the rice plant after submerged application to be around $0.9 \mathrm{ppm}^{12)}$. Therefore, flavonoid compounds added to the growth medium blocked the induction of cyanide-resistant respiration in mycelia of rice blast fungus treated with SSF $-126^{7}$. Therefore, the inhibitory effect of SSF-126 on conidial germination in the presence of rice leaf homogenate is assumed to be by inhibiting the respiration of $P$. oryzae as it invades the host cell. Certain flavonoid compounds which are naturally existing or inducibly formed in the host tissues may block the induction of the alternative pathway of respiration in the invading mycelia.

The known modes of action of current fungicides for rice blast are as follows: 1) direct inhibition of spore germination or germ tube elongation (fungicides such as organic phosphate compounds), 2) inhibition of penetration (inhibitors of melanin biosynthesis or formation of penetration hyphae), 3) induction of a defense response of the rice plant (probenazole ${ }^{11)}$ ) and 4) disturbance of membrane function or biosynthesis of membrane constituents (ferimzone ${ }^{101}$ ). However, SSF-126 does not completely inhibit conidial germination, appressorial formation or penetration (Table 1), but gives excellent control in the field ${ }^{9)}$ and a strong fungicidal effect in the presence of rice component(s) (Fig. 2) even at low concentrations $^{12)}$. These findings with SSF-126 propose a different mode of action for the fungicide.

Further experiments are needed to clarify whether SSF-126 alone is able to induce rice defense responses including generation and/or increase of flavonoid compounds in rice plant.

\section{Literature cited}

1. Ammermann, E., Lorenz, G., Schelberger, K., Wenderoth, B., Sauter, H. and Rentzea, C. (1992). BAS $490 \mathrm{~F}$ a broad-spectrum fungicide with a new mode of action. Proc. Br. Crop Prot. Conf. Pests Dis. 1 : 403-410.

2. Beautement, K., Clough, M., DeFraine, P.J. and Godfrey, C.R.A. (1991). Fungicidal $\beta$-methoxyacrylates: from natural products to novel synthetic agricultural fungicides. Pestic. Sci. $31: 499-519$.

3. Godwin, J.R., Anthony, V.M., Clough, J.M. and Godfrey, C.R.A. (1992). ICIA5504, a novel, broad spectrum, systemic $\beta$-methoxyacrylate fungicide. Proc. Br. Crop Prot. Conf. Pests Dis. 1 : 435-442.

4. Hayase, Y., Kataoka, T., Masuko, M., Niikawa, M., Ichinari, M., Takenaka, H., Takahashi, T., Hayashi, Y. and Takeda, R. (1995). Phenoxyphenyl alkoxyiminoacetamides: New broad-spectrum fungicides. In Proceedings of ACS Symposium series 584, Synthesis and Chemistry of Agrochemicals IV (Baker, D.R., Fenys, J.G. and Basarab, G.S. eds.), pp.343-353.

5. Ikeda, M., Miki, N., Kawaguchi, A., Katoh, K. and
Masuko, M. (1995). Effect of SSF-126 in rice blast through histological investigation. Ann. Phytopathol. Soc. Jpn. $61: 211$ (Abstr. in Japanese).

6. Masuko, M., Kataoka, T., Niikawa, M., Ichinari, M., Takenaka, H., Hayase, Y., Hayashi, Y. and Takeda, R. (1994). Synthesis and fungicidal characteristics of phenoxyphenyl alkoxyiminoacetamides, a new group of broad spectrum fungicide. In Abstracts of Papers, Eighth IUPAC International Congress of Pesticide Chemistry, Washington, D.C., p. 898.

7. Mizutani, A., Miki, N., Yukioka, H., Tamura, H. and Masuko, M. (1996). A possible mechanism of control of rice blast disease by a novel alkoxyiminoacetamide fungicide, SSF-126. Phytopathology $86: 295-300$.

8. Mizutani, A., Yukioka, H., Tamura, H., Miki, N. and Masuko, M. (1995). Respiratory characteristics in Pyricularia oryzae exposed to a novel alkoxyiminoacetamide fungicide. Phytopathology $85: 306-311$.

9. Niikawa, M., Kashino, H., Kawaguchi, A. and Masuko, M. (1994). Effect of a novel fungicide, SSF-126, on the control of rice blast and sheath blight. Proc. Kansai P1. Prot. Soc. 36 : 104 (Abstr. in Japanese).

10. Okuno, T., Furusawa, I., Matsuura, K. and Shishiyama, J. (1989). Mode of action of ferimzone, a novel systemic fungicide for rice disease: Biological properties against Pyricularia oryzae in vitro. Phytopathology 79: 827-832.

11. Sekizawa, Y., Haga, M., Hirabayashi, E., Takeuchi, N. and Takino, Y. (1987). Dynamic behavior of superox. ide generation in rice leaf tissue infected with blast fungus and its regulation by some substances. Agric. Biol. Chem. 51 : 763-770.

12. Tashima, S., Kume, R., Matsumoto, K., Ando, I., Doteuchi, M. and Shiraishi, T. (1997). Effect of controlled release granule on behavior of SSF-126 in paddy water, paddy soil and rice plant. J. Pestic. Sci. 22(2) (in press).

13. Woloshuk, C.R., Wolkow, P.M. and Sisler, H.D. (1981). The effect of three fungicides, specific for the control of rice blast disease, on the growth and melanin biosynthesis by Pyricularia oryzae. Cav. Pestic. Sci. 12 :86-90.

\section{和 文 摘 要}

久米龍一・新川 求・川口 章・八隅慶一郎・益子道生・白石 友紀：新規メトキシイミノアセトアミド系殺菌剈 SSF-126の 活性発現に対するイネ葉成分の関与について

イネいもち病に対して高い防除活性を示すSSF-126は，イネ いもち病菌 (Pyricularia oryzae) のスライドグラス上での分生 胞子発芽やセロファン膜侵入を $1.0 \mathrm{ppm}$ 以上の濃度においても 完全には阻害せず, また, メラニン合成阻害も示さなかった。し かし,イネ体磨砕物の共存下では発芽を顕著に阻害した。以上の 結果とこれまでの報告から, (1) SSF-126 は侵入したイネいもち 病菌の呼吸を阻害するが, (2) いもち病菌体にシアン耐性呼吸算 が誘導される。しかし，(3) イネ体中のフラボノイド化合物によ ってこの誘導過程が阻害され, その結果いもち病菌は侵入後夏 延出来ず発病に至らないと推定した。これは本剤がいもち病菌 のイネ体侵入後に活性を発現するというこれまでの知見をよく 説明しており，新規制御剤開発の指標となる機構の一つと考え られた。

(Received August 28, 1996 ; Accepted December 30, 1996) 